\title{
Evaluation of the In Vitro Antiplasmodial, Antileishmanial, and Antitrypanosomal Activity of Medicinal Plants Used in Saudi and Yemeni Traditional Medicine
}

\author{
Ramzi A. Mothana, ${ }^{1,2}$ Nawal M. Al-Musayeib, ${ }^{1}$ Mohamed F. Al-Ajmi, ${ }^{1}$ \\ Paul Cos, ${ }^{3}$ and Louis Maes ${ }^{3}$ \\ ${ }^{1}$ Department of Pharmacognosy, College of Pharmacy, King Saud University, P.O. Box 2457, Riyadh 11451, Saudi Arabia \\ ${ }^{2}$ Department of Pharmacognosy, Faculty of Pharmacy, Sana'a University, P.O. Box 33039, Sana'a, Yemen \\ ${ }^{3}$ Laboratory for Microbiology, Parasitology and Hygiene (LMPH), Faculty of Pharmaceutical, \\ Biomedical and Veterinary Sciences, Antwerp University, Universiteitsplein 1, 2610 Antwerp, Belgium \\ Correspondence should be addressed to Ramzi A. Mothana; r_mothana@yahoo.com
}

Received 28 January 2014; Accepted 30 April 2014; Published 21 May 2014

Academic Editor: José Luis Ríos

Copyright (C) 2014 Ramzi A. Mothana et al. This is an open access article distributed under the Creative Commons Attribution License, which permits unrestricted use, distribution, and reproduction in any medium, provided the original work is properly cited.

\begin{abstract}
The antiplasmodial, antileishmanial, and antitrypanosomal activity of twenty-five medicinal plants distributed in Saudi Arabia and Yemen was evaluated. The plants were extracted with methanol and screened in vitro against erythrocytic schizonts of Plasmodium falciparum, intracellular amastigotes of Leishmania infantum and Trypanosoma cruzi, and free trypomastigotes of T. brucei. To assess selectivity, cytotoxicity was determined on MRC-5 cells. Criteria for activity were an $\mathrm{IC}_{50}<10 \mu \mathrm{g} / \mathrm{mL}$ and high selectivity (SI). Seven plants showed interesting antiprotozoal activity in one or more models. Extracts of Caralluma penicillata and Acalypha ciliata showed fairly good activity against $P$. falciparum with $\mathrm{IC}_{50}$ of 6.7 and $10.8 \mu \mathrm{g} / \mathrm{mL}$ and adequate selectivity (SI $>9.6$ and $>5.9$ ). Interesting activity against $L$. infantum was obtained with Verbascum bottae (IC ${ }_{50}$ of $3.2 \mu \mathrm{g} / \mathrm{mL}$, SI 10.2) and Solanum glabratum $\left(\mathrm{IC}_{50} 8.1 \mu \mathrm{g} / \mathrm{mL}\right.$, SI 3.4). The extracts of C. penicillata, Leucas virgata, Loranthus regularis, and V. bottae exhibited moderate activity against T. brucei $\left(\mathrm{IC}_{50} 8.5,8.1,8.3\right.$, and $2.3 \mu \mathrm{g} / \mathrm{mL}$; SI > 7.6, 7.7, 4.3, and > 14.1). These results partly support the traditional use of some of the selected medicinal plants and warrant further investigations into the putative active constituents.
\end{abstract}

\section{Introduction}

About one billion people are afflicted with what the World Health Organization classifies as neglected tropical diseases (NTDs). A subset of life-threatening NTDs includes Kala azar (visceral leishmaniasis), sleeping sickness (African trypanosomiasis), and Chagas disease (American trypanosomiasis) which all may lead to fatal complications but are restricted to limited geographical areas and specific groups. Most current chemotherapeutics are toxic and marginally effective, must be given by injection, and become compromised by the development of drug-resistance [1]. Despite the large numbers of people at risk and the substantial burden of disease, with few exceptions, no major interventions have been developed for generations [2]. Malaria is yet another even bigger threat in many parts of the world with resistance spreading to almost all classes of antimalarials [3]. Hence, safe, effective, and more affordable therapeutics are clearly needed, whereby the natural biodiversity with its numerous plants, microorganisms, and marine organisms constitutes a broad source of potentially new molecules with great variety of structures and pharmacological potential. In addition, it is estimated that two-thirds of the world population still rely on traditional medical remedies, mostly plants, because of limited availability or affordability of pharmaceutical medicines [4].

In the present study, we evaluated twenty-five medicinal plants used in traditional medicine in Yemen and Saudi Arabia for their in vitro antiplasmodial, antileishmanial, and antitrypanosomal potential. 
TABLE 1: List of selected plants and their use in traditional medicine.

\begin{tabular}{|c|c|c|c|}
\hline Plant species & Family & Part used & Traditional uses \\
\hline Acalypha ciliata Forssk. & Euphorbiaceae & $\mathrm{L}$ & Malaria, anthelmintic, and scabies (a, d) \\
\hline Acalypha fruticosa Forssk. & Euphorbiaceae & $\mathrm{L}$ & Skin diseases, malaria, and wounds (a, b, d) \\
\hline Amaranthus viridis $\mathrm{L}$. & Amaranthaceae & $\mathrm{L}$ & Anthelmintic, cancer, and impotence $(\mathrm{a}, \mathrm{b})$ \\
\hline Barleria trispinosa (Forssk.) Vahl & Acanthaceae & $\mathrm{L}, \mathrm{S}$ & Warts $(\mathrm{a}, \mathrm{d})$ \\
\hline Caralluma penicillata (Deflers) N.E.Br. & Asclepiadaceae & $\mathrm{L}$ & Diabetes, stomach ulcer, and smallpox $(\mathrm{a}, \mathrm{c})$ \\
\hline Centaurothamus maximus (Forssk.) & Asteraceae & $\mathrm{L}$ & Wounds (a) \\
\hline \multicolumn{4}{|l|}{ Wagenitz \& Dittrich } \\
\hline Cissus rotundifolia (Forssk.) Vahl & Vitaceae & $\mathrm{L}$ & Malaria, liver disease, and otitis ( $a, b, c, d)$ \\
\hline Coccinia grandis (L.) Voigt & Cucurbitaceae & $\mathrm{L}, \mathrm{T}$ & Anthelmintic, diuretic, and pneumonia (a) \\
\hline Dichrocephala integrifolia (L.f.) O. & Asteraceae & $\mathrm{L}, \mathrm{S}$ & Wounds (a) \\
\hline \multicolumn{4}{|l|}{ Kuntze } \\
\hline Fagonia indica Burm. f. & Zygophyllaceae & $\mathrm{L}, \mathrm{T}$ & Diabetes, diuretic, and headache $(a, b, c)$ \\
\hline Forsskaolea tenacissima $\mathrm{L}$. & Urticaceae & $\mathrm{L}, \mathrm{S}$ & Diuretic, kidney disease (a) \\
\hline Gomphocarpus fruticosus (L.) Ait.f. & Asclepiadaceae & $\mathrm{L}$ & Tumors, skin disease, scabies, and itching $(a, b)$ \\
\hline Hypoestes forskalei (Vahl) R. Br. & Acanthaceae & $\mathrm{L}$ & $\begin{array}{l}\text { Fungal skin disease, scabies, itching, and warts } \\
\text { (a) }\end{array}$ \\
\hline Kedrostis foetidissima (Jacq.) Cogn. & Cucurbitaceae & $\mathrm{L}, \mathrm{S}$ & Warts (a) \\
\hline Kleinia pendula (Forssk.) DC. & Asteraceae & $\mathrm{R}$ & Otitis (a) \\
\hline Leucas virgata & Labiatae & $\mathrm{L}, \mathrm{T}$ & $\begin{array}{l}\text { Heartburn, indigestion, and stomach problems } \\
\text { (a) }\end{array}$ \\
\hline Loranthus regularis Steud. ex Sprague & Loranthaceae & $\mathrm{R}$ & Diabetes, kidney disease (a) \\
\hline Ochradenus baccatus Del. & Resedaceae & $\mathrm{L}, \mathrm{F}$ & Diuretic, antiseptic, cough, and itching $(\mathrm{a}, \mathrm{b})$ \\
\hline Otostegia fruticosa (Forssk.) Briq. & Labiatae & $\mathrm{L}, \mathrm{F}$ & Antiparalytic, eye diseases (a) \\
\hline Oxalis corniculata $\mathrm{L}$. & Oxalidaceae & $\mathrm{L}, \mathrm{F}$ & $\begin{array}{l}\text { Antiparasitic, antivertigo, and mouth } \\
\text { inflammation }(a, b, c)\end{array}$ \\
\hline Rosmarinus officinalis $\mathrm{L}$. & Labiatae & $\mathrm{L}, \mathrm{S}$ & Antiseptic, cholagogue $(\mathrm{a}, \mathrm{d})$ \\
\hline Solanum glabratum Dunal & Solanaceae & $\mathrm{L}, \mathrm{T}$ & $\begin{array}{l}\text { Diuretic, scabies, syphilis, cough, hemorrhoids } \\
(a, b, c, d)\end{array}$ \\
\hline Taraxacum officinale F.H. Wigg & Asteraceae & $\mathrm{L}$ & Gastrointestinal troubles (a) \\
\hline Tecoma stans (L.) H.B.K. & Bignoniaceae & $\mathrm{L}, \mathrm{S}$ & Diabetes $(\mathrm{a}, \mathrm{b})$ \\
\hline Verbascum bottae (Deflers) Huber-Mor. & Scrophulariaceae & $\mathrm{L}, \mathrm{F}$ & Cough, skin disease, and rheumatism $(\mathrm{a}, \mathrm{b})$ \\
\hline
\end{tabular}

F: flower, L: leaves, R: roots or rhizomes, S: stems, and T: fruits. a: information has been taken from native people; b: Al-Dubai and Al-Khulaidi (1996) [5]; c: Fleurentin and Pelt (1982) [6]; d: Schopen (1983) [7].

\section{Materials and Methods}

2.1. Plant Material. Twenty-five plants were selected randomly from different areas of Yemen and Saudi Arabia in March and June 2008 and were identified at the Pharmacognosy Departments, Colleges of Pharmacy, King Saud and Sana'a Universities, Saudi Arabia and Yemen. The plants were chosen mainly on the basis of their local medicinal knowledge. Voucher specimens were deposited at the departments. The botanical names, plant parts used, and the traditional uses in the collected areas are presented in Table 1.

2.2. Extraction of Plant Materials. The air-dried and powdered plant material (50 g) was extracted with $500 \mathrm{~mL}$ methanol $\left(\mathrm{CH}_{3} \mathrm{OH}\right)$ using a Soxhlet apparatus for 8 hours. The obtained methanolic extract was filtered and evaporated in a rotator evaporator and freeze dryer. The dried extracts were stored at $-20^{\circ} \mathrm{C}$ until used. Stock solutions were prepared in $100 \%$ DMSO at $20 \mathrm{mg} / \mathrm{mL}$ just prior to in vitro evaluation.

2.3. Reference Drugs. For the different tests, appropriate reference drugs were used as positive control: tamoxifen for MRC-5, chloroquine for Plasmodium falciparum, miltefosine for Leishmania infantum, benznidazole for Trypanosoma cruzi, and suramin for Trypanosoma brucei. All reference drugs were obtained either from the fine chemical supplier Sigma or from WHO-TDR.

2.4. Biological Assays. The integrated panel of microbial screens and standard screening methodologies were adopted as previously described [8]. All assays were performed at the Laboratory of Microbiology, Parasitology and Hygiene at the University of Antwerp, Belgium. Plant extracts were tested in 
triplicate at 5 concentrations $(64,16,4,1$, and $0.25 \mu \mathrm{g} / \mathrm{mL})$ to establish a full dose-titration and determination of the $\mathrm{IC}_{50}$ (inhibitory concentration 50\%). The in-test concentration of DMSO did not exceed $0.5 \%$.

2.4.1. Antileishmanial Activity. L. infantum MHOM/MA (BE)/67 amastigotes were collected from the spleen of an infected donor hamster and used to infect primary peritoneal mouse macrophages. Macrophages $\left(3 \times 10^{4}\right)$ were seeded in each well of a 96-well plate. After 2 days of outgrowth, $5 \times 10^{5}$ amastigotes were added to each well and incubated for $2 \mathrm{~h}$ at $37^{\circ} \mathrm{C}$. The prediluted extracts were subsequently added and the plates were further incubated for 5 days at $37^{\circ} \mathrm{C}$ and $5 \%$ $\mathrm{CO}_{2}$. Intracellular amastigotes burdens were microscopically assessed after Giemsa staining and expressed as a percentage of the burdens in the blank controls.

2.4.2. Antiplasmodial Activity. Chloroquine-resistant P. falciparum K1-strain was grown in human erythrocytes $\mathrm{O}^{+}$at $37^{\circ} \mathrm{C}$ under a low oxygen atmosphere $\left(3 \% \mathrm{O}_{2}, 4 \% \mathrm{CO}_{2}\right.$, and 93\% $\mathrm{N}_{2}$ ) in RPMI-1640 medium supplemented with $10 \%$ human serum. Infected human red blood cells $(200 \mu \mathrm{L}, 1 \%$ parasitaemia and $2 \%$ hematocrit) were added to each well containing the prediluted extracts and incubated for $72 \mathrm{~h}$. After incubation, test plates were frozen at $-20^{\circ} \mathrm{C}$ and parasite multiplication was measured by the Malstat method [9].

2.4.3. Antitrypanosomal Activity. T. brucei Squib-427 strain (suramin-sensitive) was cultured at $37^{\circ} \mathrm{C}$ and $5 \% \mathrm{CO}_{2}$ in Hirumi-9 medium [10] supplemented with $10 \%$ fetal calf serum (FCS). About $1.5 \times 10^{4}$ trypomastigotes were added to each well and parasite growth was assessed after $72 \mathrm{~h}$ at $37^{\circ} \mathrm{C}$ by adding resazurin [11]. For Chagas disease, T. cruzi Tulahuen CL2 (benznidazole-sensitive) was maintained on MRC-5 cells in minimal essential medium (MEM) supplemented with $20 \mathrm{mM}$ L-glutamine, $16.5 \mathrm{mM}$ sodium hydrogen carbonate, and 5\% FCS. In the assay, $4 \times 10^{3}$ MRC-5 cells and $4 \times 10^{4}$ parasites were added to each well. After incubation at $37^{\circ} \mathrm{C}$ for 7 days, parasite growth was assessed by adding the $\beta$-galactosidase substrate chlorophenol red $\beta$-D-galactopyranoside [12]. The color reaction was read at $540 \mathrm{~nm}$ after $4 \mathrm{~h}$ and absorbance values were expressed as a percentage of the blank controls.

2.4.4. Cytotoxicity Assay. MRC- $5_{\mathrm{Sv} 2}$ cells were cultivated in MEM supplemented with L-glutamine $(20 \mathrm{mM}), 16.5 \mathrm{mM}$ sodium hydrogen carbonate, and 5\% FCS. For the assay, $10^{4}$ MRC- 5 cells/well were seeded onto the test plates containing the prediluted extracts and incubated at $37^{\circ} \mathrm{C}$ and $5 \% \mathrm{CO}_{2}$ for $72 \mathrm{~h}$. Cell viability was assessed fluorimetrically after 4 hours of addition of resazurin. Fluorescence was measured (excitation $550 \mathrm{~nm}$, emission $590 \mathrm{~nm}$ ) and the results are expressed as \% reduction in cell viability compared to the blank controls.

\section{Results}

For the selection of relevant plant species for our screening program, different places in Yemen and Saudi Arabia were visited where elderly people with profound knowledge of folk medicine were interviewed. In total, 25 medicinal plants were collected (Table 1), extracted, and evaluated in the integrated in vitro screen for antileishmanial, antiplasmodial, and antitrypanosomal potential (Table 2). Seven plants showed interesting activity (acceptable potency and selectivity) in one or more models (Table 2).

3.1. Antiplasmodial Activity. The methanolic extracts of Caralluma penicillata and Acalypha ciliata showed relevant activity against $P$. falciparum with $\mathrm{IC}_{50}$ of 6.7 and $10.8 \mu \mathrm{g} / \mathrm{mL}$, respectively, and acceptable selectivity (SI > 9.6 and > 5.9). The extracts of Dichrocephala integrifolia and Rosmarinus officinalis showed similar activity with $\mathrm{IC}_{50}$ values of 10.2 and 11.4 but with low selectivity ( $\mathrm{SI}=2.4$ and 1.9). Hypoestes forskalei demonstrated nonselective inhibition $\left(\mathrm{IC}_{50} 8.8 \mu \mathrm{g} / \mathrm{mL} ; \mathrm{SI} 1.3\right)$.

3.2. Antileishmanial Activity. The extract of Verbascum bottae showed promising and selective activity against $L$. infantum ( $\mathrm{IC}_{50} 3.2 \mu \mathrm{g} / \mathrm{mL}$; SI 10.2); Solanum glabratum exhibited moderate antileishmanial activity $\left(\mathrm{IC}_{50} 8.1 \mu \mathrm{g} / \mathrm{mL}\right.$; SI 3.4). H. forskalei demonstrated nonselective inhibition $\left(\mathrm{IC}_{50}\right.$ $8.1 \mu \mathrm{g} / \mathrm{mL}$; SI 1.4).

3.3. Antitrypanosomal Activity. Against T. brucei, the extracts of C. penicillata, Leucas virgata, Loranthus regularis, and $V$. bottae exhibited the most remarkable activity with $\mathrm{IC}_{50}$ values of $8.5,8.1,8.3$, and $2.3 \mu \mathrm{g} / \mathrm{mL}$, respectively, and acceptable selectivity (SI > 7.6, 7.7, 4.3, and > 14.1). Against T. cruzi, some inhibitory potential was shown for D. integrifolia, $R$. officinalis, and S. glabratum, however, with lower selectivity $\left(\mathrm{IC}_{50} 6.6,8.8\right.$, and $8.5 \mu \mathrm{g} / \mathrm{mL}$, resp., with $\left.\mathrm{SI}<4\right)$.

3.4. Cytotoxicity. The selectivity of the antiprotozoal activity was assessed on MRC-5 cells. Clear cytotoxicity was found for Gomphocarpus fruticosus ( $\mathrm{IC}_{50} 2.3 \mu \mathrm{g} / \mathrm{mL}$ ), Centaurothamus maximus $\left(\mathrm{IC}_{50} 9.3 \mu \mathrm{g} / \mathrm{mL}\right.$ ), and Hypoestes forskalei $\left(\mathrm{IC}_{50}\right.$ $11.0 \mu \mathrm{g} / \mathrm{mL}$ ). The observed antiprotozoal inhibition of these plant species is therefore considered as nonselective.

\section{Discussion}

In continuation of our search for substances of plant origin with pharmacological effects, 25 plants were collected from Saudi Arabia and Yemen and screened for their antiplasmodial, antileishmanial, and antitrypanosomal activity potential. It is important to mention that to the best of our knowledge, this study represents the first report on antiprotozoal evaluation for most of the investigated plants. Although some plants have already been partly investigated, knowledge remains very limited in many cases. Based on 
TABLE 2: Antiprotozoal activity and cytotoxicity $\left(\mathrm{IC}_{50}-\mu \mathrm{g} / \mathrm{mL}\right)$ of the methanolic extracts of the investigated plants.

\begin{tabular}{|c|c|c|c|c|c|c|c|c|c|}
\hline \multirow{2}{*}{ Plant species } & \multirow{2}{*}{$\begin{array}{l}\text { P. falciparum } \\
\mathrm{IC}_{50}\end{array}$} & \multicolumn{3}{|c|}{ L. infantum } & \multirow{2}{*}{$\begin{array}{c}\text { T. cruzi } \\
\mathrm{IC}_{50} \\
\end{array}$} & \multicolumn{3}{|c|}{ T. brucei } & \multirow{2}{*}{$\begin{array}{c}\text { MRC-5 } \\
\mathrm{IC}_{50} \\
\end{array}$} \\
\hline & & SI & $\mathrm{IC}_{50}$ & SI & & SI & $\mathrm{IC}_{50}$ & SI & \\
\hline Acalypha ciliata & $10.8 \pm 1.3$ & $>5.9$ & $>64.0$ & & $34.4 \pm 7.3$ & $>1.9$ & $32.7 \pm 3.7$ & $>2.0$ & $>64.0$ \\
\hline Acalypha fruticosa & $27.1 \pm 6.2$ & $>2.4$ & $>64.0$ & & $35.7 \pm 5.8$ & $>1.8$ & $32.9 \pm 4.1$ & $>2.0$ & $>64.0$ \\
\hline Amaranthus polygamus & $>64.0$ & $>1$ & $>64.0$ & & $>64.0$ & & $>64.0$ & & $>64.0$ \\
\hline Barleria trispinosa & $59.8 \pm 5.6$ & $>1.1$ & $>64.0$ & & $>64.0$ & & $>64.0$ & & $>64.0$ \\
\hline Caralluma penicillata & $6.7 \pm 0.9$ & $>9.6$ & $34.6 \pm 4.5$ & $>1.9$ & $28.0 \pm 1.7$ & $>2.3$ & $8.5 \pm 1.5$ & $>7.6$ & $>64.0$ \\
\hline Centaurothamus maximus & $12.1 \pm 3.4$ & $<1$ & $32.5 \pm 0.5$ & $<1$ & $8.3 \pm 0.7$ & 1.1 & $35.8 \pm 2.3$ & & $9.3 \pm 1.8$ \\
\hline Cissus rotundifolia & $>64.0$ & $>$ & $>64.0$ & & $>64.0$ & & $>64.0$ & & $>64.0$ \\
\hline Coccinia grandis-fruits & $>64.0$ & $>$ & $>64.0$ & & $>64.0$ & & $>64.0$ & & $>64.0$ \\
\hline Coccinia grandis-leaves & $38.6 \pm 7.3$ & $>1.7$ & $43.1 \pm 4.8$ & $>1.5$ & $36.9 \pm 2.4$ & $>1.7$ & $32.7 \pm 4.3$ & $>2$ & $>64.0$ \\
\hline Dichrocephala integrifolia & $10.2 \pm 2.5$ & 2.4 & $20.3 \pm 2.6$ & 1.2 & $6.6 \pm 0.5$ & 3.7 & $37.6 \pm 4.9$ & & $24.5 \pm 3.7$ \\
\hline Fagonia indica & $>64.0$ & & $>64.0$ & & $>64.0$ & & $>64.0$ & & $>64.0$ \\
\hline Forsskaoleatenacissima & $>64.0$ & & $>64.0$ & & $>64.0$ & & $>64.0$ & & $>64.0$ \\
\hline Gomphocarpus fruticosus & $>64.0$ & & $>64.0$ & & $2.6 \pm 0.5$ & 1 & $>64.0$ & & $2.3 \pm 0.4$ \\
\hline Hypoestes forskalei & $8.8 \pm 2.0$ & 1.3 & $8.1 \pm 1.3$ & 1.4 & $9.1 \pm 1.0$ & $>1.2$ & $8.1 \pm 0.5$ & $>1.4$ & $11.0 \pm 2.1$ \\
\hline Kedrostis foetidissima & $62.2 \pm 8.3$ & $>1$ & $>64.0$ & & $60.2 \pm 3.5$ & $>1.1$ & $>64.0$ & & $>64.0$ \\
\hline Kleinia pendula & $38.9 \pm 6.4$ & $>1.6$ & $>64.0$ & & $32.3 \pm 3.7$ & $>2$ & $32.7 \pm 4.0$ & $>2$ & $>64.0$ \\
\hline Leucas virgata & $>64.0$ & & $>64.0$ & & $>64.0$ & & $8.3 \pm 0.9$ & $>7.7$ & $>64.0$ \\
\hline Loranthus regularis & $>64.0$ & & $32.5 \pm 0.5$ & 1.3 & $33.6 \pm 2.5$ & 1.2 & $9.5 \pm 2.1$ & 4.3 & $40.6 \pm 5.5$ \\
\hline Ochradenus baccatus & $>64.0$ & & $>64.0$ & & $>64.0$ & & $>64.0$ & & $>64.0$ \\
\hline Otostegia fruticosa & $34 \pm 5.2$ & $>1.9$ & $>64.0$ & & $36.6 \pm 4.9$ & $>1.8$ & $35.2 \pm 3.7$ & $>1.8$ & $>64.0$ \\
\hline Oxalis corniculata & $>64.0$ & & $>64.0$ & & $54.7 \pm 7.6$ & $>1.2$ & $34.7 \pm 5.2$ & $>1.8$ & $>64.0$ \\
\hline Rosmarinus officinalis & $11.4 \pm 2.7$ & 1.9 & $32.5 \pm 0.5$ & & $8.8 \pm 1.2$ & 2.5 & $13.2 \pm 2.0$ & 1.7 & $22.1 \pm 1.7$ \\
\hline Solanum glabratum & $>64.0$ & & $8.1 \pm 1.3$ & 3.4 & $8.5 \pm 0.9$ & 3.3 & $30.0 \pm 4.8$ & & $27.9 \pm 3.4$ \\
\hline Taraxacum officinale & $>64.0$ & & $>64.0$ & & $45.6 \pm 7.3$ & $>1.4$ & $>64.0$ & & $>64.0$ \\
\hline Tecoma stans & $36.3 \pm 5.8$ & $>1.8$ & $38.1 \pm 4.7$ & $>1.7$ & $31.7 \pm 3.7$ & $>2.0$ & $36.9 \pm 6.3$ & $>1.7$ & $>64.0$ \\
\hline Verbascum bottae & $29.9 \pm 4.5$ & 1.1 & $3.2 \pm 0.3$ & 10.2 & $27.0 \pm 4.2$ & 1.2 & $2.3 \pm 0.9$ & 14.1 & $32.5 \pm 5.9$ \\
\hline Chloroquine & $0.3 \pm 0.1$ & & & & & & & & \\
\hline Miltefosine & & & $3.32 \pm 0.7$ & & & & & & \\
\hline Benznidazole & & & & & $2.2 \pm 0.5$ & & & & \\
\hline Suramin & & & & & & & $0.03 \pm 0.02$ & & \\
\hline Tamoxifen & & & & & - & & & & $11.0 \pm 2.3$ \\
\hline
\end{tabular}

$\mathrm{IC}_{50}$ values of reference drugs are expressed in $\mu \mathrm{M}$ concentrations.

potency $\left(\mathrm{IC}_{50}\right)$ and selectivity, seven plant extracts are considered promising enough to pursue further purification and biological evaluation of individual constituents.

The methanol extract of the C. penicillata (collected from Saudi Arabia) exhibited antiplasmodial activity with adequate selectivity ( $\mathrm{IC}_{50} 6.7 \mu \mathrm{g} / \mathrm{mL}$, SI 9.6). Some side-activity was present against $T$. brucei $\left(\mathrm{IC}_{50} 8.5 \mu \mathrm{g} / \mathrm{mL}\right.$, SI 7.6), which matches our previously published data on $C$. sinaica showing antileishmanial and antitrypanosomal activity. However, $C$. sinaica was inactive against $P$. falciparum [13]. Pregnane glycosides which represent the major compounds in Caralluma species are believed to be responsible for the observed effects. Isolation and characterization of some acylated pregnane glycosides revealed antiparasitic activity for C. tuberculata and $C$. penicillata. The pregnane glycosides penicilloside $\mathrm{E}$ isolated from $C$. penicillata and caratuberside $C$ isolated from C. tuberculata exhibited a pronounced antitrypanosomal activity $\left(\mathrm{IC}_{50} 1.0\right.$ and $\left.1.8 \mu \mathrm{g} / \mathrm{mL}\right)[14,15]$.
Interesting antiplasmodial activity was obtained with $A$. ciliata that is traditionally used in the treatment of malaria. Our result is in agreement with literature data on other Acalypha species [16-20]. We previously reported interesting antiplasmodial activity for the methanol and aqueous extracts of $A$. fruticosa [16], whereby both extracts showed complete inhibition of schizont maturation at $7.8 \mu \mathrm{g} / \mathrm{mL}$. Furthermore, Bradacs et al. [17] reported that the leaf extracts of $A$. grandis significantly affected $P$. falciparum without showing obvious effects on other protozoa. Additionally, the extract and fractions of $A$. wilkesiana dose-dependently reduced parasitaemia induced by chloroquine-sensitive $P$. berghei infection in prophylactic, suppressive, and curative mouse models [18].

Interesting antileishmanial and antitrypanosomal activities were observed for S. glabratum. Antiprotozoal properties have indeed been reported for extracts from other Solanum species [21-25]. Abdel-Sattar et al. [21] demonstrated potent 
in vitro antitrypanosomal activity for the methanol extract of S. schimperianum $\left(\mathrm{IC}_{50} 0.061 \mu \mathrm{g} / \mathrm{mL}\right)$. It is recently reported that the extract of $S$. torvum inhibited the proliferation of promastigotes of L. donovani [22]. The fruits of S. stramonifolium var. stramonifolium were shown to have marginal activity against amastigotes of L. amazonensis [23]. Although S. sisymbriifolium failed to inhibit promastigotes of L. amazonensis and L. brasiliensis ( $\mathrm{IC}_{50}$ of 33.8 and $20.5 \mu \mathrm{g} / \mathrm{mL}$ ), the steroid derivative Cilistol-A as the main active principle of the chloroform fraction exhibited significant activity against both Leishmania species ( $\mathrm{IC}_{50} 6.6$ and $3.1 \mu \mathrm{g} / \mathrm{mL}$ ) [24]. It seems that the antileishmanial as well as antitrypanosomal activities can be attributed to the steroidal alkaloids, which represent the major constituents in Solanum species. Abreu Miranda et al. [25] isolated solamargine and solasonine from the fruits of S. lycocarpum and showed in vitro leishmanicidal activity against promastigotes of L. amazonensis. Our failure to demonstrate activity against P. falciparum $\left(\mathrm{IC}_{50}>\right.$ $64 \mu \mathrm{g} / \mathrm{mL}$ ) is not in agreement with literature data on other Solanum species. For example, Chinchilla et al. [26] reported antimalarial effect for S. arboretum; Kamaraj et al. [27] found some effect for $S$. torvum against chloroquine-sensitive (3D7) and chloroquine-resistant strains of $P$. falciparum. Moreover, diosgenone which is a spirostan-type steroidal saponin isolated from $S$. nudum, showed a high activity against FCB2 strain of $P$. falciparum [28]. These results showed that diosgenone could be a new therapeutic alternative for the treatment of malaria [28].

One of the more remarkable plants with antileishmanial and antitrypanosomal activities was $V$. bottae, which showed selective activity against $L$. infantum and $T$. brucei $\left(\mathrm{IC}_{50} 3.2\right.$ and $2.3 \mu \mathrm{g} / \mathrm{mL}$; SI 10.2 and 14.1). This result outperforms data reported on other Verbascum species. A very marginal antileishmanial activity for $V$. arcturus against $L$. donovani $\left(\mathrm{IC}_{50} 57 \mu \mathrm{g} / \mathrm{mL}\right.$ ) was reported and no activity against $P$. falciparum was reported [29]. Manjili et al. [30] obtained an $\mathrm{IC}_{50}$ of $451 \mu \mathrm{g} / \mathrm{mL}$ for a $V$. thapsus extract against L. major promastigotes, illustrating inefficacy.

Another plant with antitrypanosomal activity was $L$. virgata $\left(\mathrm{IC}_{50} 8.8 \mu \mathrm{g} / \mathrm{mL}\right.$ against T. brucei), which is in agreement with literature data on other Leucas species [31-34]. Our results on the antiplasmodial inactivity of $L$. virgata are not in agreement with the effects noted for $L$. aspera and $L$. cephalotes. It is recently reported that the leaf ethyl acetate and methanol extracts of $L$. aspera had good antiplasmodial activity $\left(\mathrm{IC}_{50} 7.81\right.$ and $22.7 \mu \mathrm{g} / \mathrm{mL}$ with SI values of 5.4 and 2.0) [32]. A similar study was conducted by Kamaraj et al. [33] who reported similar results for $L$. aspera $\left(\mathrm{IC}_{50} 12.5 \mu \mathrm{g} / \mathrm{mL}\right)$. In addition, it is reported that $L$. cephalotes showed promising antiplasmodial activity $\left(\mathrm{IC}_{50}<5 \mu \mathrm{g} / \mathrm{mL}\right)$ in addition to promising activities against $L$. donovani with $\mathrm{IC}_{50}$ values of $3.61 \mu \mathrm{g} / \mathrm{mL}(\mathrm{SI}=8)$ [34]. Apparently, these findings are mostly attributed to the presence of essential oil constituents as well as diterpenoids [35-38]. Triterpenoids, such as ursolic acid isolated from some Leucas species [39], showed significant antitrypanosomal activity: it inhibited all movement of $T$. cruzi epimastigotes at $40 \mu \mathrm{g} / \mathrm{mL}$ after $48 \mathrm{~h}$ incubation [40].

Notably antitrypanosomal potencies against T. brucei were also displayed by the methanolic extract of $L$. regularis
$\left(\mathrm{IC}_{50} 9.5 \mu \mathrm{g} / \mathrm{mL}, \mathrm{SI} 4.3\right)$. Based on the literature review and to the best of our knowledge this is the first report on antiprotozoal activity of the genus Loranthus.

The methanolic extract of $R$. officinalis inhibited both $P$. falciparum and T. cruzi ( $\mathrm{IC}_{50} 11.4$ and $8.8 \mu \mathrm{g} / \mathrm{mL}$; SI 1.9 and 2.5) which is in agreement with data reported previously $[35,40]$. The inhibitory effect was attributed to the presence of essential oils and triterpenoids, such as ursolic acid and oleanolic acid [40].

\section{Conclusion}

In conclusion, this preliminary study led to the identification of seven plant extracts, namely, A. ciliata, C. pencillata, $L$. virgata, L. regularis, $R$. officinalis, S. glabratum, and V. bottae exhibiting relevant antiplasmodial, antileishmanial, and antitrypanosomal activity in one or more models. The obtained results support to some extent the traditional uses of some plants for the treatment of parasitic diseases. Isolation, purification, and structure elucidation of constituents from some of these investigated plants are warranted to support discovery of novel antiplasmodial, antileishmanial, and antitrypanosomal compounds.

\section{Conflict of Interests}

The authors declare that there is no conflict of interests regarding the publication of this paper.

\section{Acknowledgments}

This project was supported by NSTIP Strategic Technologies Programs no. (10-MED1288-02) in the Kingdom of Saudi Arabia. The authors extend their appreciation for that support. Matheeussen and Margot Desmet are acknowledged for performing the in vitro screening work and processing of the data.

\section{References}

[1] M. M. Salem and K. A. Werbovetz, "Natural products from plants as drug candidates and lead compounds against leishmaniasis and trypanosomiasis," Current Medicinal Chemistry, vol. 13, no. 21, pp. 2571-2598, 2006.

[2] World Health Organization (WHO), "Research priorities for chagas disease, human African trypanosomiasis and leishmaniasis," Technical Report Series 975, WHO, Geneva, Switzerland, 2012.

[3] D. Ganesh, H. P. Fuehrer, P. Starzengrüber et al., "Antiplasmodial activity of flavonol quercetin and its analogues in Plasmodium falciparum: evidence from clinical isolates in Bangladesh and standardized parasite clones," Parasitology Research, vol. 110, no. 6, pp. 2289-2295, 2012.

[4] S. Hoet, F. Opperdoes, R. Brun, and J. Quetin-Leclercq, "Natural products active against African trypanosomes: a step towards new drugs," Natural Product Reports, vol. 21, no. 3, pp. 353-364, 2004.

[5] A. S. Al-Dubai and A. A. Al-khulaidi, Medicinal and Aromatic Plants of Yemen (in Arabic), Obadi Center, Sana'a, Yemen, 1996. 
[6] J. Fleurentin and J. M. Pelt, "Repertory of drugs and medicinal plants of Yemen," Journal of Ethnopharmacology, vol. 6, no. 1, pp. 85-108, 1982.

[7] A. Schopen, Traditionelle Heilmittel in Jemen, Franz Steiner, Berlin, Germany, 1983.

[8] P. Cos, A. J. Vlietinck, D. V. Berghe, and L. Maes, "Anti-infective potential of natural products: how to develop a stronger in vitro 'proof-of-concept,' Journal of Ethnopharmacology, vol. 106, no. 3, pp. 290-302, 2006.

[9] M. T. Makler, J. M. Ries, J. A. Williams et al., "Parasite lactate dehydrogenase as an assay for Plasmodium falciparum drug sensitivity," American Journal of Tropical Medicine and Hygiene, vol. 48, no. 6, pp. 739-741, 1993.

[10] H. Hirumi and K. Hirumi, "Continuous cultivation of Trypanosoma brucei blood stream forms in a medium containing a low concentration of serum protein without feeder cell layers," Journal of Parasitology, vol. 75, no. 6, pp. 985-989, 1989.

[11] B. Raz, M. Iten, Y. Grether-Buhler, R. Kaminsky, and R. Brun, "The Alamar Blue assay to determine drug sensitivity of African trypanosomes (T. b. rhodesiense, T. b. gambiense) in vitro," Acta Tropica, vol. 68, no. 2, pp. 2592-2597, 1997.

[12] F. S. Buckner, C. L. Verlinde, A. C. La Flamme, and W. C. Van Voorhis, "Efficient technique for screening drugs for activity against Trypanosoma cruzi using parasites expressing betagalactosidase," Antimicrobial Agents and Chemotherapy, vol. 40, no. 11, pp. 2592-2597, 1996.

[13] N. M. Al-Musayeib, R. A. Mothana, S. Al-Massarani, A. Matheeussen, P. Cos, and L. Maes, "Study of the in vitro antiplasmodial, antileishmanial and antitrypanosomal activities of medicinal plants from Saudi Arabia," Molecules, vol. 17, no. 10, pp. 11379-11390, 2012.

[14] E. Abdel-Sattar, F. M. Harraz, S. M. A. Al-ansari et al., "Acylated pregnane glycosides from Caralluma tuberculata and their antiparasitic activity," Phytochemistry, vol. 69, no. 11, pp. 21802186, 2008.

[15] E. Abdel-Sattar, F. M. Harraz, S. M. A. Al-Ansari et al., "Antiplasmodial and antitrypanosomal activity of plants from the Kingdom of Saudi Arabia," Journal of Natural Medicines, vol. 63, no. 2, pp. 232-239, 2009.

[16] M. A. Alshawsh, R. A. Mothana, H. A. Al-Shamahy, S. F. Alsllami, and U. Lindequist, "Assessment of antimalarial activity against Plasmodium falciparum and phytochemical screening of some Yemeni medicinal plants," Evidence Based Complementary and Alternative Medicine, vol. 6, no. 4, pp. 453-456, 2009.

[17] G. Bradacs, L. Maes, and J. Heilmann, "In Vitro cytotoxic, antiprotozoal and antimicrobial activities of medicinal plants from Vanuatu," Phytotherapy Research, vol. 24, no. 6, pp. 800-809, 2010.

[18] J. A. Udobang, P. A. Nwafor, and J. E. Okokon, "Analgesic and antimalarial activities of crude leaf extract and fractions of Acalypha wilkensiana," Journal of Ethnopharmacology, vol. 127, no. 2, pp. 373-378, 2010.

[19] M. C. Navarro, M. P. Montilla, M. M. Cabo et al., "Antibacterial, antiprotozoal and antioxidant activity of five plants used in izabal for infectious diseases," Phytotherapy Research, vol. 17, no. 4, pp. 325-329, 2003.

[20] E. O. Okanla, J. A. Owoyale, and J. A. Akinyanju, "Trypanocidal effect of an aqueous extract of Acalypha hispida leaves," Journal of Ethnopharmacology, vol. 29, no. 2, pp. 233-237, 1990.

[21] E. Abdel-Sattar, N. G. Shehab, C. Ichino et al., "Antitrypanosomal activity of some pregnane glycosides isolated from
Caralluma species," Phytomedicine, vol. 16, no. 6-7, pp. 659-664, 2009.

[22] D. J. Hubert, N. Céline, N. Michel et al., "In Vitro leishmanicidal activity of some Cameroonian medicinal plants," Experimental Parasitology, vol. 134, no. 3, pp. 304-308, 2013.

[23] Y. Estevez, D. Castillo, M. T. Pisango et al., "Evaluation of the leishmanicidal activity of plants used by Peruvian Chayahuita ethnic group," Journal of Ethnopharmacology, vol. 114, no. 2, pp. 254-259, 2007.

[24] V. C. Filho, C. Meyre-Silva, R. Niero et al., "Evaluation of antileishmanial activity of selected Brazilian plants and identification of the active principles," Evidence Based Complementary and Alternative Medicine, vol. 2013, Article ID 265025, 7 pages, 2013.

[25] M. Abreu Miranda, R. F. Tiossi, M. R. da Silva et al., "In Vitro leishmanicidal and cytotoxic activities of the glycoalkaloids from Solanum lycocarpum (Solanaceae) fruits," Chemistry and Biodiversity, vol. 10, no. 4, pp. 642-648, 2013.

[26] M. Chinchilla, I. Valerio, R. Sánchez et al., "In Vitro antimalarial activity of extracts of some plants from a biological reserve in Costa Rica," Revista de Biologia Tropical, vol. 60, no. 2, pp. 881891, 2012.

[27] C. Kamaraj, N. K. Kaushik, D. Mohanakrishnan et al., "Antiplasmodial potential of medicinal plant extracts from Malaiyur and Javadhu hills of South India," Parasitology Research, vol. 111, no. 2, pp. 703-715, 2012.

[28] G. Alvarez, A. Pabón, J. Carmona, and S. Blair, "Evaluation of clastogenic potential of the antimalarial plant Solanum nudum," Phytotherapy Research, vol. 18, no. 10, pp. 845-848, 2004.

[29] N. Fokialakis, E. Kalpoutzakis, B. L. Tekwani et al., "Evaluation of the antimalarial and antileishmanial activity of plants from the Greek island of Crete," Journal of Natural Medicines, vol. 61, no. 1, pp. 38-45, 2007.

[30] H. K. Manjili, H. Jafari, A. Ramazani, and N. Davoudi, "Antileishmanial and toxicity activities of some selected Iranian medicinal plants," Parasitology Research, vol. 111, no. 5, pp. 21152121, 2012.

[31] N. M. Al-Musayeib, R. A. Mothana, A. Matheeussen, P. Cos, and L. Maes, "In Vitro antiplasmodial, antileishmanial and antitrypanosomal activities of selected medicinal plants used in the traditional Arabian Peninsular region," BMC Complementery and Alternative Medicine, vol. 12, p. 49, 2012.

[32] A. Bagavan, A. A. Rahuman, C. Kamaraj, N. K. Kaushik, D. Mohanakrishnan, and D. Sahal, "Antiplasmodial activity of botanical extracts against Plasmodium falciparum," Parasitology Research, vol. 108, no. 5, pp. 1099-1109, 2011.

[33] C. Kamaraj, N. K. Kaushik, A. A. Rahuman et al., "Antimalarial activities of medicinal plants traditionally used in the villages of Dharmapuri regions of South India," Journal of Ethnopharmacology, vol. 141, no. 3, pp. 796-802, 2012.

[34] V. K. Dua, G. Verma, D. D. Agarwal, M. Kaiser, and R. Brun, "Antiprotozoal activities of traditional medicinal plants from the Garhwal region of North West Himalaya, India," Journal of Ethnopharmacology, vol. 136, no. 1, pp. 123-128, 2011.

[35] S. B. Ahmed, R. M. Sghaier, F. Guesmi et al., "Evaluation of antileishmanial, cytotoxic and antioxidant activities of essential oils extracted from plants issued from the leishmaniasisendemic region of Sned (Tunisia)," Natural Product Research, vol. 25, no. 12, pp. 1195-1201, 2011.

[36] P. Escobar, S. M. Leal, L. V. Herrera, J. R. Martinez, and E. Stashenko, "Chemical composition and antiprotozoal activities of 
Colombian Lippia spp essential oils and their major components," Memorias do Instituto Oswaldo Cruz, vol. 105, no. 2, pp. 184-190, 2010.

[37] T. Moon, J. M. Wilkinson, and H. M. A. Cavanagh, "Antiparasitic activity of two Lavandula essential oils against Giardia duodenalis, Trichomonas vaginalis and Hexamita inflata," Parasitology Research, vol. 99, no. 6, pp. 722-728, 2006.

[38] S. K. Sadhu, E. Okuyama, H. Fujimoto, and M. Ishibashi, "Diterpenes from Leucas aspera inhibiting prostaglandin-induced contractions," Journal of Natural Products, vol. 69, no. 7, pp. 988994, 2006.

[39] S. N. Das, V. J. Patro, and S. C. A. Dinda, "A review: ethnobotanical survey of genus Leucas," Pharmacognosy Reviews, vol. 6, no. 12, pp. 100-106, 2012.

[40] F. Abe, T. Yamauchi, T. Nagao et al., "Ursolic acid as a trypanocidal constituent in rosemary," Biological and Pharmaceutical Bulletin, vol. 25, no. 11, pp. 1485-1487, 2002. 


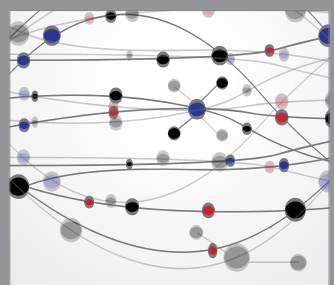

The Scientific World Journal
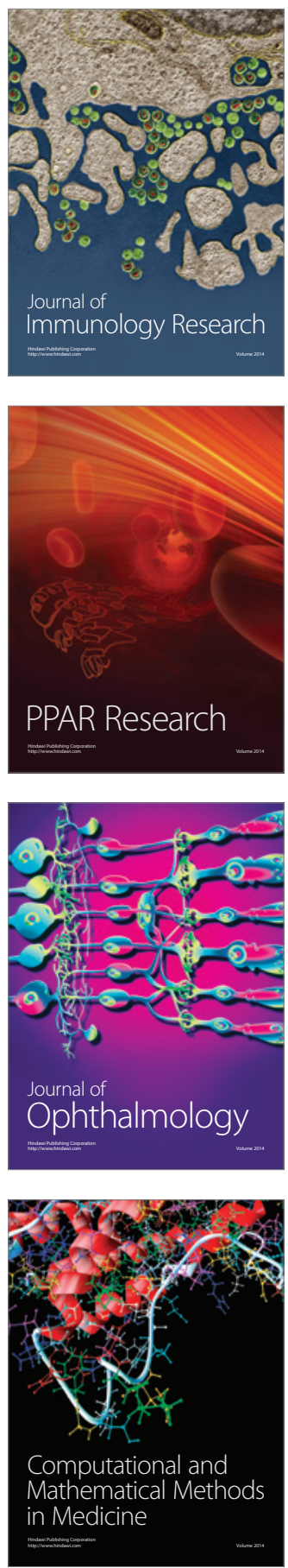

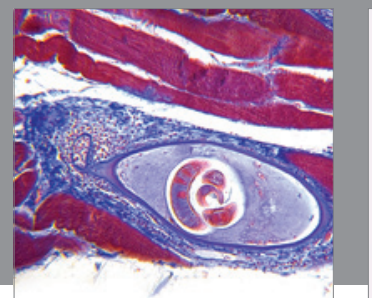

Gastroenterology

Research and Practice
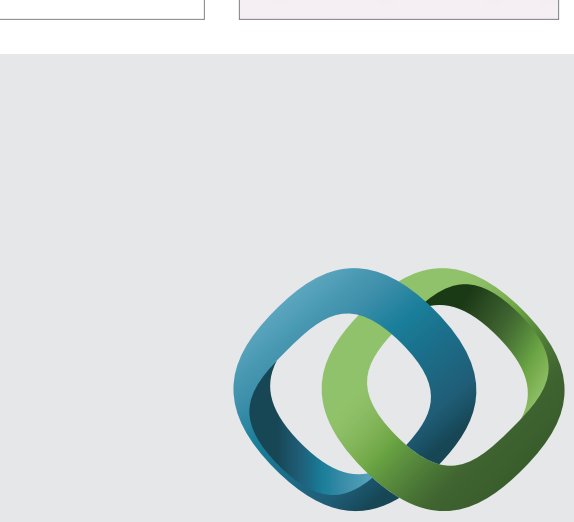

\section{Hindawi}

Submit your manuscripts at

http://www.hindawi.com
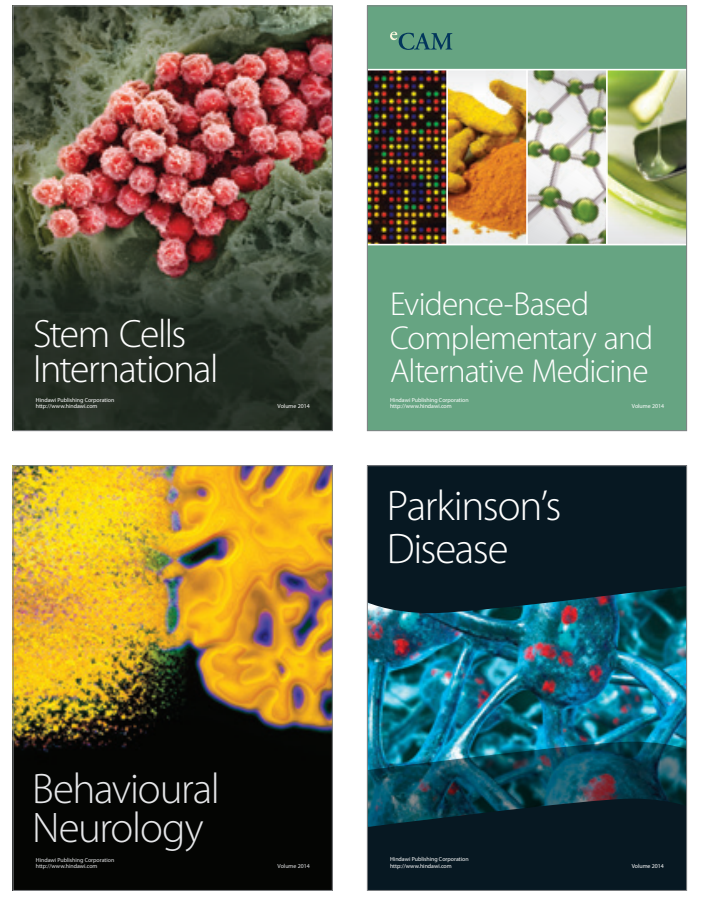
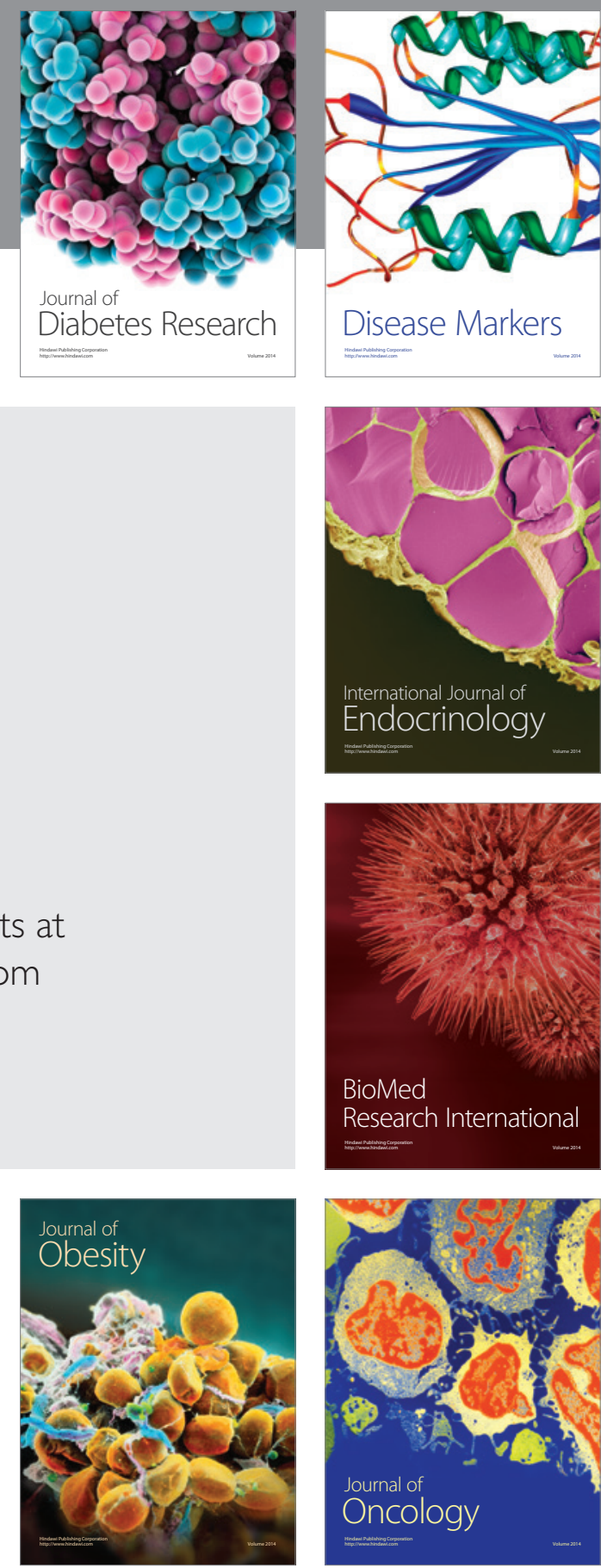

Disease Markers
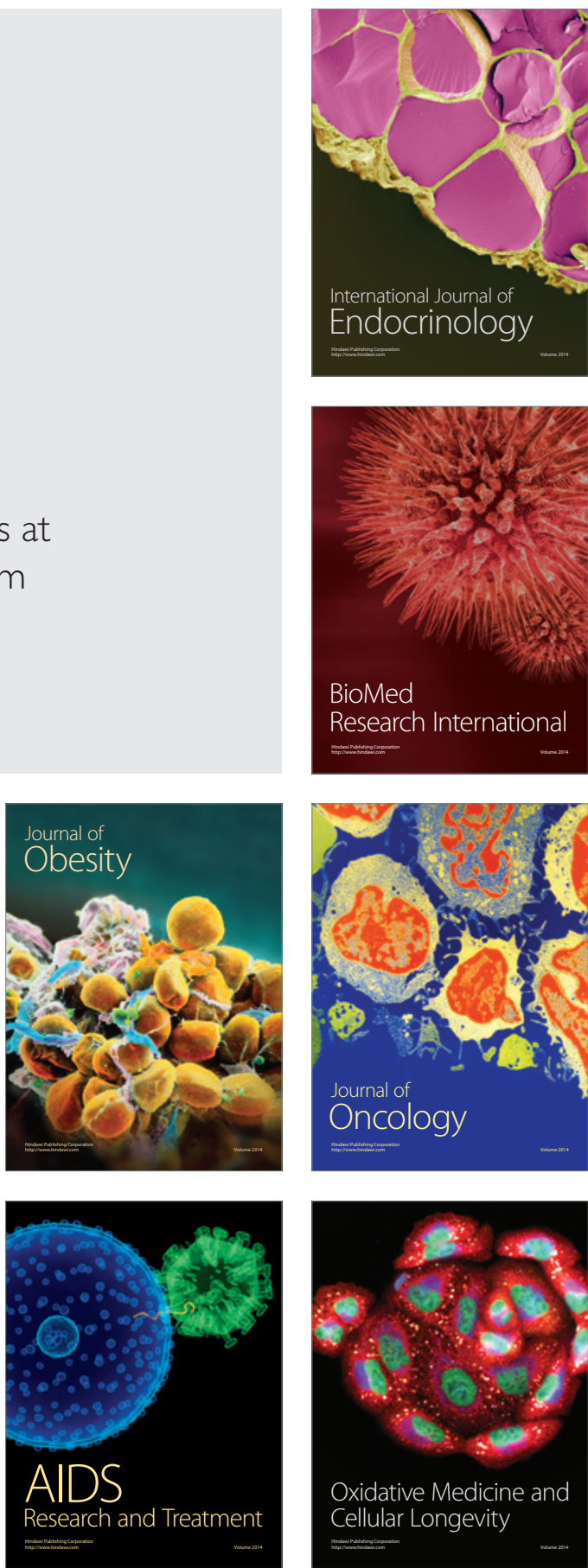